\title{
Amelioration of Mitochondrial Quality Control and Proteostasis by Natural Compounds in Parkinson's Disease Models
}

\author{
Bongki Cho ${ }^{1,+}$, Taeyun Kim ${ }^{2,3,+}$, Yu-Jin Huh ${ }^{2,3,+}$, Jaemin Lee ${ }^{2, * \text { DD }}$ and Yun-Il Lee ${ }^{1,3, *}$ \\ 1 Division of Biotechnology, Daegu Gyeongbuk Institute of Science and Technology, Daegu 42988, Korea; \\ cbk34@dgist.ac.kr \\ 2 Department of New Biology, Daegu Gyeongbuk Institute of Science and Technology, Daegu 42988, Korea; \\ xoxsdfaa7876@dgist.ac.kr (T.K.); yujin.huh@dgist.ac.kr (Y.-J.H.) \\ 3 Well Aging Research Center, Daegu Gyeongbuk Institute of Science and Technology, Daegu 42988, Korea \\ * Correspondence: jaeminlee@dgist.ac.kr (J.L.); ylee56@dgist.ac.kr (Y.-I.L.) \\ + These authors contributed equally to this work.
}

Received: 4 October 2019; Accepted: 17 October 2019; Published: 21 October 2019

\begin{abstract}
Parkinson's disease (PD) is a well-known age-related neurodegenerative disorder associated with longer lifespans and rapidly aging populations. The pathophysiological mechanism is a complex progress involving cellular damage such as mitochondrial dysfunction and protein homeostasis. Age-mediated degenerative neurological disorders can reduce the quality of life and also impose economic burdens. Currently, the common treatment is replacement with levodopa to address low dopamine levels; however, this does not halt the progression of PD and is associated with adverse effects, including dyskinesis. In addition, elderly patients can react negatively to treatment with synthetic neuroprotection agents. Recently, natural compounds such as phytochemicals with fewer side effects have been reported as candidate treatments of age-related neurodegenerative diseases. This review focuses on mitochondrial dysfunction, oxidative stress, hormesis, proteostasis, the ubiquitin-proteasome system, and autophagy (mitophagy) to explain the neuroprotective effects of using natural products as a therapeutic strategy. We also summarize the efforts to use natural extracts to develop novel pharmacological candidates for treatment of age-related PD.
\end{abstract}

Keywords: Parkinson's disease (PD); mitochondrial dysfunction; dynamics; hormesis; proteostasis; ubiquitin-proteasome system (UPS); autophagy; mitophagy; natural compounds

\section{Introduction}

Parkinson's disease (PD) is the second most common neurodegenerative disease. Approximately $1 \%$ of the elderly population above 60 years of age suffers from PD, and the prevalence of the disease increases to $4 \%$ in the highest age group [1]. Because the incidence of PD depends strongly on age, the number of PD patients is estimated to dramatically increase as lifespans also increase. The economic burden of PD was estimated to be $\$ 14.4$ billion in the United States in 2010 [2]. However, it increased up to $\$ 51.9$ billion in 2017 [3], and is expected to increase more dramatically in the future. The most effective therapeutic option is the administration of 1-3,4-dihydroxyphenylalanine (L-DOPA), which can cross the blood-brain barrier and be metabolized to dopamine [4]. However, all currently available drugs, including L-DOPA, only modulate dopamine levels in PD patients' brains and are of limited effectiveness in the initial stages of the disease, which can last for 1-5 years [5]. Novel strategies are therefore needed to prevent and manage PD in the later stages.

PD is histologically characterized by the progressive loss of dopaminergic (DA) neurons in the substantia nigra pars compacta (SNpc), which innervates basal ganglia and regulates motor control 
through the release of dopamine. The loss of DA neurons occurs before the onset of motor symptoms [6]. At the end stage of PD, neuronal degeneration become widespread, resulting in various symptoms. Another notable characteristic of PD is Lewy pathology (LP), particularly within the brain stem and olfactory system during early-stage PD. As the disease progresses, LP spreads to the limbic and neocortical regions of the brain. LP is usually observed in PD patients' brains using histopathological methods [7]. However, LP is also observed in non-PD human brains, making LP a poor predictor of PD [8].

\subsection{Major Pathological Mechanisms of Neurodegeneration in PD}

The mechanism of PD pathogenesis has been studied extensively, although questions remain $[9,10]$. In brief, impairment of quality control in mitochondria and proteins by oxidative stress, and $\alpha$-synuclein accumulation, is the primary mechanism associated with degeneration of DA neurons in PD with neuroinflammation [10]. Because this pathological mode is a common characteristic in other neurodegenerative diseases, including Alzheimer's disease and amyotrophic lateral sclerosis, we will discuss PD-specific pathological mechanisms of mitochondrial quality control and proteostasis.

\subsection{Impairment of Mitochondrial Quality Control}

Several genes have been identified to be related with early-onset PD, and their physiological roles have been extensively studied. Parkin and PINK1 are major components for autophagy-mediated degradation of mitochondria (mitophagy), and their genetic mutations are closely related with accumulation of dysfunctional mitochondria in early-onset PD [11,12]. In addition, DJ-1 is critical for the antioxidant process against oxidative stress, which is induced by $\mathrm{Ca}^{2+}$ oscillation in autonomously pacemaking DA neurons $[13,14]$, and its autosomal recessive mutation is also related with early-onset PD [15]. These observations suggest a pathological role of mitochondrial dysfunction in early-onset and potentially sporadic PD. Especially, decreased activity of mitochondrial respiratory chain complex I has been observed in post-mortem SNpc of sporadic PD patients [16]. Neurotoxins, such as 6-hydroxydopamine (6-OHDA), 1-methyl-4-phenyl-1,2,3,6-tetrahydropyridine/ 1-methyl-4-phenyl-pyridinium (MPTP/MPP ${ }^{+}$) and rotenone have been frequently used for experimental PD model. They inhibit the activity of mitochondrial respiratory chain complex I, and aberrantly induce mitochondrial dysfunction by oxidative stress, thereby mimicking selective loss of DA neurons in SNpc $[17,18]$. These indicate that impairment of mitochondrial function is linked with PD pathology.

Impairment on mitochondrial turnover also appears in PD [19]. Mitochondrial turnover is mediated by two pathways; 1) morphological balance between fusion and fission, and 2) qualitative and quantitative balance between biogenesis and mitophagy. Mitochondrial fragmentation has been well known as a common phenomenon in early stage of neuropathology including PD [20]. And reversely, mdivi-1, a synthetic blockade of mitochondrial fission as an inhibitor of Dynamin-related protein 1 (DRP1) [21], efficiently rescues DA neurons in a genetically- and chemically-induced PD model [22,23], emphasizing a critical contribution of mitochondrial dynamics in PD pathology. In addition, level of genes controlled by proliferator-activated receptor gamma coactivator 1-alpha (PGC1 $\alpha$ ), which is a master transcription factor for mitochondrial biogenesis, are downregulated in the brains of PD patients [24]. Reversely, activation of PGC-1 $\alpha$ signaling efficiently reduces $\alpha$-synuclein toxicity [25]. Furthermore, overexpression of Parkin prevented degeneration of DA neuron in PD model through activating mitophagy [26]. Those studies suggest that the activation of mitochondrial quality control can be a strategy to prevent and manage sporadic PD.

\subsection{Impairment of Proteostasis}

The second pathological mechanism of PD is abnormal accumulation of misfolded proteins by impairment of proteostasis. $\alpha$-synuclein has been reported to be a major component in Lewy bodies in PD patients, and its mutation is involved in early-onset PD [10], raising the possibility that $\alpha$-synuclein aggregates may play a critical role in PD pathogenesis. Although the physiological role 
of $\alpha$-synuclein remains to be understood, the detrimental outcome of $\alpha$-synuclein oligomers and aggregates has been widely studied. In pathological conditions, $\alpha$-synuclein can oligomerize and form insoluble fibrils [27]. The $\alpha$-synuclein oligomer induces aberrant generation of reactive oxygen species by inhibiting mitochondrial respiratory complex I, and leads to mitochondrial dysfunction [28]. Enhancement of proteostasis of $\alpha$-synuclein by preventing aggregation and/or clearing aggregates can therefore be an effective strategy to cope with PD. A study in transgenic mice expressing human $\alpha$-synuclein demonstrated that both the ubiquitin-proteasome system (UPS) and autophagy-lysosome pathway are responsible for the degradation of $\alpha$-synuclein in neurons [29]. Rapamycin, an inhibitor of the mammalian target of rapamycin, consistently promotes degradation of wild-type and mutant $\alpha$-synuclein [30] and rescues loss of DA neurons and parkinsonism in a 6-OHDA-induced PD mouse model [31]. These observations suggest that the activation of proteostasis mechanisms can be an effective strategy to manage PD through $\alpha$-synuclein clearance.

Parkin plays a critical role in mitophagy [26] and gene transcription [32] as a PD-related multifunctional E3 ligase. Parkin targets, ubiquitinates, and degrades other proteins as well as the substrates involved in mitophagy. For instance, the genetic inactivation of Parkin leads to the accumulation of ZNF746 (PARIS), a substrate of Parkin, and this process represses PGC- $1 \alpha$ signaling, leading to the degeneration of DA neurons [33]. PARIS accumulates excessively and consistently in familiar and sporadic PD patients' brain, indicating a pathophysiological role in PD. Parkin also ubiquitinates and degrades the aminoacyl-tRNA synthetase complex interacting multifunctional protein-2, which activates poly(ADP-ribose) polymerase- 1 and promotes PAR polymerization, resulting in neuronal death via "parthanatos" [34,35]. These studies suggest a crucial role for E3 ligase activity of Parkin in the PD-related degeneration of DA neurons. Activation of UPS by Parkin or other E3 ligase may therefore also offer a crucial neuroprotective effect against PD.

\section{Compounds from Natural Products Alleviating Mitochondrial Dysfunction in PD}

\subsection{Recovery of Redox Homeostasis}

We list 84 lead compounds isolated from natural products that have neuroprotective effect in vitro and/or in vivo experimental PD models according to their chemical class with effect summary (Table 1). Among them, the reaction of some natural compounds in mitochondrial quality control is summarized in Figure 1. Oxidative stress has been proposed as a main initial factor in mitochondrial dysfunction, which appears as an early pathological event in neurodegenerative diseases, including PD [36]. Mitochondria are the main endogenous source of various free radicals, including reactive oxygen species/reactive nitrogen species (ROS/RNS) via oxidative phosphorylation and are removed by redox enzymes including catalase, superoxide dismutase, and heme oxigenase- 1 with intracellular antioxidants such as glutathione (GSH) [37]. However, the failure of redox homeostasis induces excessive levels of ROS/RNS, leading to mitochondrial dysfunction [36]. Neurotoxins in experimental PD models, such as 6-OHDA, $\mathrm{MPP}^{+} / \mathrm{MPTP}$, rotenone, and paraquat, impair redox homeostasis by reducing the amount of antioxidants and activity of redox enzymes [38]. Traditionally, many compounds from natural products that recover redox homeostasis have been suggested for mitochondrial quality control in PD. Pre- or cotreatment of the compounds efficiently reduces levels of ROS/RNS against PD-related neurotoxins. Although the compounds, which are classified as polyphenols, terpenes, saponins, alkaloids, and other classes, exhibit anti-oxidizing activity in vitro, they may work as cellular activators and/or messengers by increasing the amount of GSH and by enhancing the activity of redox enzymes. Some mechanistic studies have revealed that nuclear factor erythroid 2-related factor 2 (NRF2) plays a central role in activating the redox system for neuroprotection against PD. Upon oxidative stress, NRF2 is stabilized by escaping from the UPS, which is mediated by Kelch-like ECH-associated protein 1 (KEAP1) and Cullin-3 (CUL3) [39]. Therefore, it accumulates in the nucleus and binds to promoters of multiple redox enzyme genes as a transcriptional activator, leading to the expression of redox enzymes as a defensive response. This process is enhanced by the following 
compounds: baicalein [40], luteolin [41], naringenin [42], puerarin [43] and genistein [44], auraptene [45], resveratrol [46], 11-dehydrosinulariolide [47], tanshinone I/IIA [48,49], astaxanthin [50], notoginsenoside $\operatorname{Rg} 2 / \operatorname{Rd} / \operatorname{Re}$ [51,52], ligustrazine [53], fucoidan [54], gastrodin [55], 3,4-dihydroxyphenyl-lactic acid [56], and salidroside [57]. However, some compounds induce expression of DJ-1, which promotes the recovery of the redox system via SOD1 and NRF2 signaling [58]. Among them are naringenin [59], sesamol [59], 11-dehydrosinulariolide [47], salidroside [57], rutin [60], and isoquercitrin [60]. Previous studies have demonstrated that various polyphenols and terpenes can evoke NRF2 signaling in other cellular contexts and environments [54]. This implies that other listed compounds can also activate NRF2 signaling, and their mechanistic study in PD models should be pursued. Taken together, we suggest that recovery of redox homeostasis is a basic property of natural compounds in PD treatment.

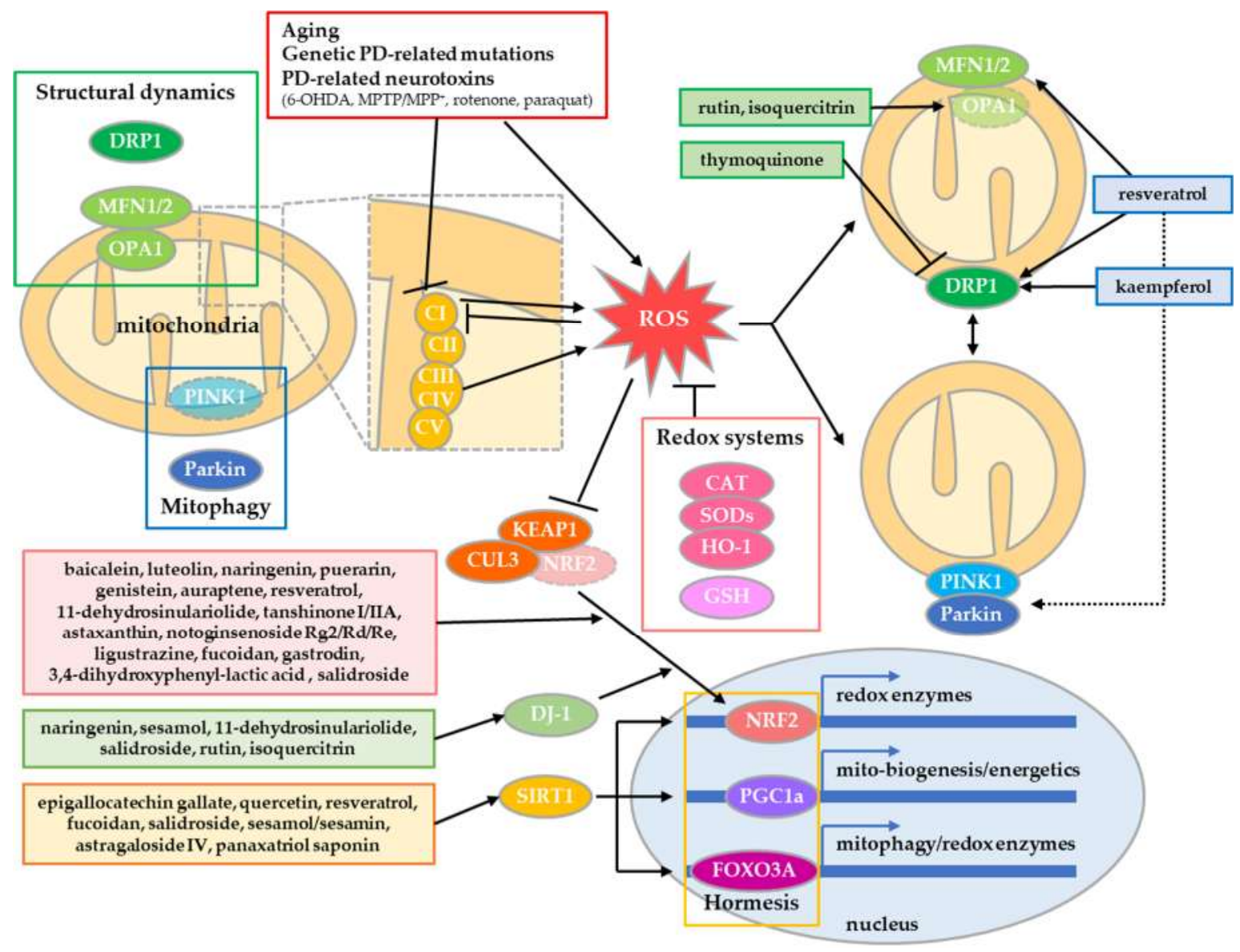

Figure 1. Neuroprotective compounds via mitochondrial quality control in PD. Mitochondrial quality is controlled by redox systems, structural dynamics, and mitophagy. In addition, it can be enhanced by hormetic adaptive stress responses. Some natural compounds revert and/or enhance redox system by NRF2 signaling, and improve mitochondrial quality by controlling structural dynamics and mitophagy. In addition, some compounds evoke adaptive stress responses mediated by SIRT1, which induce gene expression involved in redox enzymes, mitochondrial biogenesis/energetics and mitophagy. Therefore, these compounds protect DA neurons in PD. 
Table 1. Lead compounds from natural products having neuroprotective effect in experimental PD model.

\begin{tabular}{|c|c|c|c|c|c|c|c|c|c|}
\hline Class & Compounds & MitoQC & ProteoQC & Refs. & Class & Compounds & MitoQC & ProteoQC & Refs. \\
\hline \multirow{19}{*}{ polyphenol/flavonoid } & $\begin{array}{l}\text { Epigallocatechin } \\
\text { gallate }\end{array}$ & 0 & $\bigcirc$ & {$[61,62]$} & \multirow{4}{*}{ terpene/diterpene } & 11-Dehydrosinulariolide & $\Delta$ & $\Delta$ & [47] \\
\hline & Apigenin & $\bigcirc$ & $\bigcirc$ & {$[63,64]$} & & Tanshinone I & $\bigcirc$ & $\bigcirc$ & {$[48,65]$} \\
\hline & Baicalein & $\bigcirc$ & $\bigcirc$ & {$[40,66]$} & & Tanshinone IIA & $\bigcirc$ & 0 & {$[49,65]$} \\
\hline & Luteolin & 0 & 0 & {$[41,67]$} & & Triptolide & & 0 & {$[68]$} \\
\hline & Naringenin & 0 & O & {$[42,59]$} & \multirow{3}{*}{ terpene/triterpene } & Celastrol & 0 & O & {$[69,70]$} \\
\hline & Puerarin & O & O & {$[43,71]$} & & Ursolic acid & 0 & & [72] \\
\hline & Quercetin & 0 & 0 & {$[73,74]$} & & Asiaticoside A & 0 & & [75] \\
\hline & Rutin & 0 & $\Delta$ & {$[60,76]$} & terpene/sesquiterpene & Nerolidol & 0 & & [77] \\
\hline & Isoquercitrin & O & $\Delta$ & {$[60]$} & \multirow{9}{*}{ saponin } & Astragaloside IV & 0 & O & {$[78,79]$} \\
\hline & Kaempferol & 0 & $\Delta$ & {$[80,81]$} & & Gypenosides & O & & [82] \\
\hline & Isoliquiritigenin & 0 & & [83] & & Notoginsenoside Rg1 & 0 & & [51] \\
\hline & Genistein & O & & [44] & & Panaxatriol saponin & 0 & & [84] \\
\hline & Biochanin A & 0 & & [85] & & Onjisaponin B & $\Delta$ & O & [86] \\
\hline & Hesperidin & 0 & & [87] & & Ginsenoside Rb1 & & 0 & [88] \\
\hline & Morin & 0 & & [89] & & Ginsenoside Rd & 0 & & [52] \\
\hline & Myricetin & 0 & & {$[90,91]$} & & Ginsenoside Re & 0 & & [52] \\
\hline & Dihydromyricetin & 0 & $\bigcirc$ & {$[92,93]$} & & Ginsenoside Rg1 & 0 & 0 & {$[94,95]$} \\
\hline & Troxerutin & 0 & & [96] & \multirow{5}{*}{ alkaloid } & Ligustrazine & 0 & O & [53] \\
\hline & Liquiritigenin & 0 & $\bigcirc$ & [97] & & Isorhynchophylline & 0 & $\bigcirc$ & {$[98,99]$} \\
\hline \multirow{4}{*}{ polyphenol/coumarin } & Auraptene & 0 & & [45] & & Conophylline & $\Delta$ & 0 & [100] \\
\hline & Fraxetin & 0 & & [101] & & Amurensin G & & 0 & [102] \\
\hline & Esculin & 0 & & [103] & & 6-Hydroxy-N-acetyl- $\beta$-oxotryptamine & O & & [104] \\
\hline & Esculetin & 0 & & [105] & diketo-piperazine & Mactanamide & 0 & & [104] \\
\hline
\end{tabular}


Table 1. Cont.

\begin{tabular}{|c|c|c|c|c|c|c|c|c|c|}
\hline Class & Compounds & MitoQC & ProteoQC & Refs. & Class & Compounds & MitoQC & ProteoQC & Refs. \\
\hline \multirow{3}{*}{ polyphenol/cinnamate } & Chlorogenic acid & o & O & {$[106,107]$} & \multirow{2}{*}{ polyketide } & 8-Methoxy-3,5-dimethylisochroman-6-ol & O & & [104] \\
\hline & Curcumin & ○ & $\bigcirc$ & {$[90,108]$} & & 3-O-Methylorsellinic acid & 0 & & [104] \\
\hline & Rosmarinic acid & ○ & 0 & {$[109,110]$} & \multirow{2}{*}{ dibenzofuran } & Candidusin A & 0 & & [104] \\
\hline \multirow{6}{*}{ polyphenol/stilbene } & Resveratrol & O & 0 & {$[46,111-113]$} & & 4"-Dehydroxycandidusin A & 0 & & [104] \\
\hline & Piceatannol & O & & [105] & mannose & Mannosylglycerate & & 0 & [114] \\
\hline & $\begin{array}{l}\text { 2,3,5,4'-tetrahydr- } \\
\text { oxystilbene-2-O- } \beta \text { - } \\
\text { D-glucoside }\end{array}$ & 0 & O & {$[115,116]$} & deoxy-adenosine & Cordycepin & O & & [117] \\
\hline & Salvianolic acid A & $\circ$ & $\Delta$ & {$[118,119]$} & \multirow{3}{*}{ polysaccharide } & Sulfated hetero-polysaccharides & $\circ$ & & [120] \\
\hline & Salvianolic acid B & O & O & {$[93,121]$} & & Sulfated galactofucan polysaccharides & ○ & & [120] \\
\hline & Polydatin & o & & {$[122]$} & & Fucoidan & o & $\Delta$ & {$[54,123,124]$} \\
\hline polyphenol/xanthone & Mangiferin & $\circ$ & & [125] & \multirow{2}{*}{ quinone } & Thymoquinone & 0 & 0 & {$[126,127]$} \\
\hline \multirow{3}{*}{ polyphenol/lignan } & Sesamol & 0 & 0 & {$[59,128]$} & & 2-methoxy-6-acetyl-7-methyljuglone & 0 & & [129] \\
\hline & Sesamin & o & & [128] & anisole & $\beta$-asarone & o & ○ & [130] \\
\hline & Magnolol & ○ & & {$[131,132]$} & benzofurans & 3-n-butylphthalide & ○ & O & [133] \\
\hline \multirow{3}{*}{ terpene/carotenoid } & Crocetin & O & ○ & {$[134,135]$} & glucoside & Gastrodin & O & & [55] \\
\hline & Crocin & o & O & {$[135,136]$} & bibenzyl & Chrysotoxine & 0 & & [137] \\
\hline & Astaxanthin & 0 & O & {$[50,138]$} & indolizine & Corynoxine B & $\Delta$ & 0 & [139] \\
\hline \multirow{3}{*}{ terpene/monoterpene } & Paeoniflorin & 0 & 0 & {$[140,141]$} & iridoid & Oleuropein & O & & [76] \\
\hline & Catalpol & O & & [142] & lactate & 3,4-dihydroxyphenyl-lactic acid & O & & [56] \\
\hline & Isoborneol & 0 & & [143] & phenol-glycoside & Salidroside & $\Delta$ & 0 & {$[57,144,145]$} \\
\hline
\end{tabular}

We list the lead compounds in natural products having a neuroprotective effect in PD, and summarize their effects according to mitochondrial quality control (MitoQC) and protein quality

control (ProteoQC), with references. Open circles or triangles indicate the existence of direct or indirect evidence in the literature, respectively. 


\subsection{Enhancement of Mitochondrial Turnover by Structural Dynamics}

Recent papers have revealed the importance of structural quality control of mitochondria in neurodegeneration, including PD [20]. In the intra-/extracellular environment, mitochondria undergo dynamic morphological changes via controlled fusion and fission, which are mediated by fusion proteins, mitofusin $1 / 2$ and optic atrophy 1 (OPA1), and the fission protein DRP1 [146]. This process contributes to mitochondrial quality and bioenergetics by the sharing and division of metabolites and nucleoids in mitochondria (Figure 1). However, PD-related neurotoxins and genetic mutations can induce excessive fragmentation of mitochondria by enhancing fission or inhibiting fusion, resulting in excessive mitophagy and eventual mitochondria-mediated neuronal death [19]. As a result of this discovery, compounds that inhibit mitochondrial fragmentation in PD models have been proposed. Thymoquinone reverts rotenone-induced upregulation of DRP1 protein in substantia nigra and striatum in PD model rats [126]. Rutin and isoquercitrin recover the expression of OPA1 in 6-OHDA-treated PC12 cells [60]. Moreover, other compounds promote mitochondrial turnover by enhancing the overall activity of fusion/fission or mitophagy. Resveratrol upregulates the expression of both MFN1/2 and DRP1, resulting in the upscaling of mitochondrial quality by enhanced fusion/fission of mitochondria in PD models [111,112]. Kaempferol induces mitochondrial fragmentation, which contributes to efficient mitophagy, thereby protecting neurons from accumulation of abnormal mitochondria [80]. Rosmarinic acid protects membrane integrity in mitochondria against permeabilization by $\alpha$-synuclein aggregates [109].

\subsection{Natural Compounds Evoking Mitochondrial Hormesis}

Hormesis-evoking therapeutic trials in PD have been conducted because the pathology of sporadic PD is closely linked with mitochondrial aging [147]. Hormesis is an adaptive response against severe challenges by enhancing functionality and tolerance upon preconditioned mild intracellular or extra-environmental stress [148]. Especially, mitochondrial hormesis can be evoked in response to mild mitochondrial stressors, including energetic depletion, calcium, and ROS by adaptive endoplasmic reticulum (ER)/integrated stress response and mitochondrial unfolded protein response [149]. This process promotes biogenesis, energetics, antioxidant response, protein quality control, and mitophagy of mitochondria, thereby extending lifespans with reduced metabolism via cytokine-mediated systemic regulation. Treatment with epigallocatechin gallate [61], quercetin [73], resveratrol [113] or fucoidan [123], sesamol/sesamin [128], astragaloside IV [78], panaxatriol saponin [84], or salidroside [144] in PD models activates sirtuin 1 (SIRT1) signaling, which promotes PGC1 $\alpha$ signaling and Forkhead box O3 signaling, which are involved in the biogenesis/bioenergetics and mitophagy/redox of mitochondria, respectively [149]. In addition, rutin and oleuropein upregulate IRE1 $\alpha$ and ATF-4 without activating CHOP, PERK, BIP, and PDI in low hormetic doses, thereby improving cell survival [76]. However, relatively high doses of panaxatriol saponin, rutin, and oleuropein inhibit cell growth and proliferation, indicating some toxic effect. Therefore, these hormesis-evoking compounds may require more intensive study on the dose-response [76,84]. SIRT1 signaling also activates the NRF2-mediated activation of the redox system via PGC1 $\alpha$ signaling [149]. Therefore, NRF2-activating compounds may have a potential hormetic effect, but this possibility requires further study.

\section{Natural Compounds Ameliorating Proteostasis Impairment in PD}

The best-described pathological feature of PD is compromised proteostasis, which can be induced by oxidative or nitrosative stress resulting from misfolded protein accumulation and other exogenous neurotoxins $[150,151]$. In this section, we focus on two major mechanisms involved in proteostasis impairment with PD onset: UPS and autophagy. Autosomal recessive mutations of Parkin represent a large proportion of familial PD [152,153], and disruption of Parkin-mediated proteolysis leads to excessive protein misfolding, which culminates in PD [154]. On the other hand, $\alpha$-synuclein forms fibril 
aggregates via PD-associated progressive posttranslational modifications, and it is usually degraded by autophagy-lysosome machinery. However, pathologically excessive $\alpha$-synuclein aggregates impair the autophagy-lysosome machinery, leading to the vicious establishment of PD [155]. Researchers have therefore focused on ameliorating the collapsed protein quality for PD by controlling translation, chaperone-assisted folding and the degradation of protein. The regulation on proteostasis machinery by natural compounds is summarized in Figure 2.

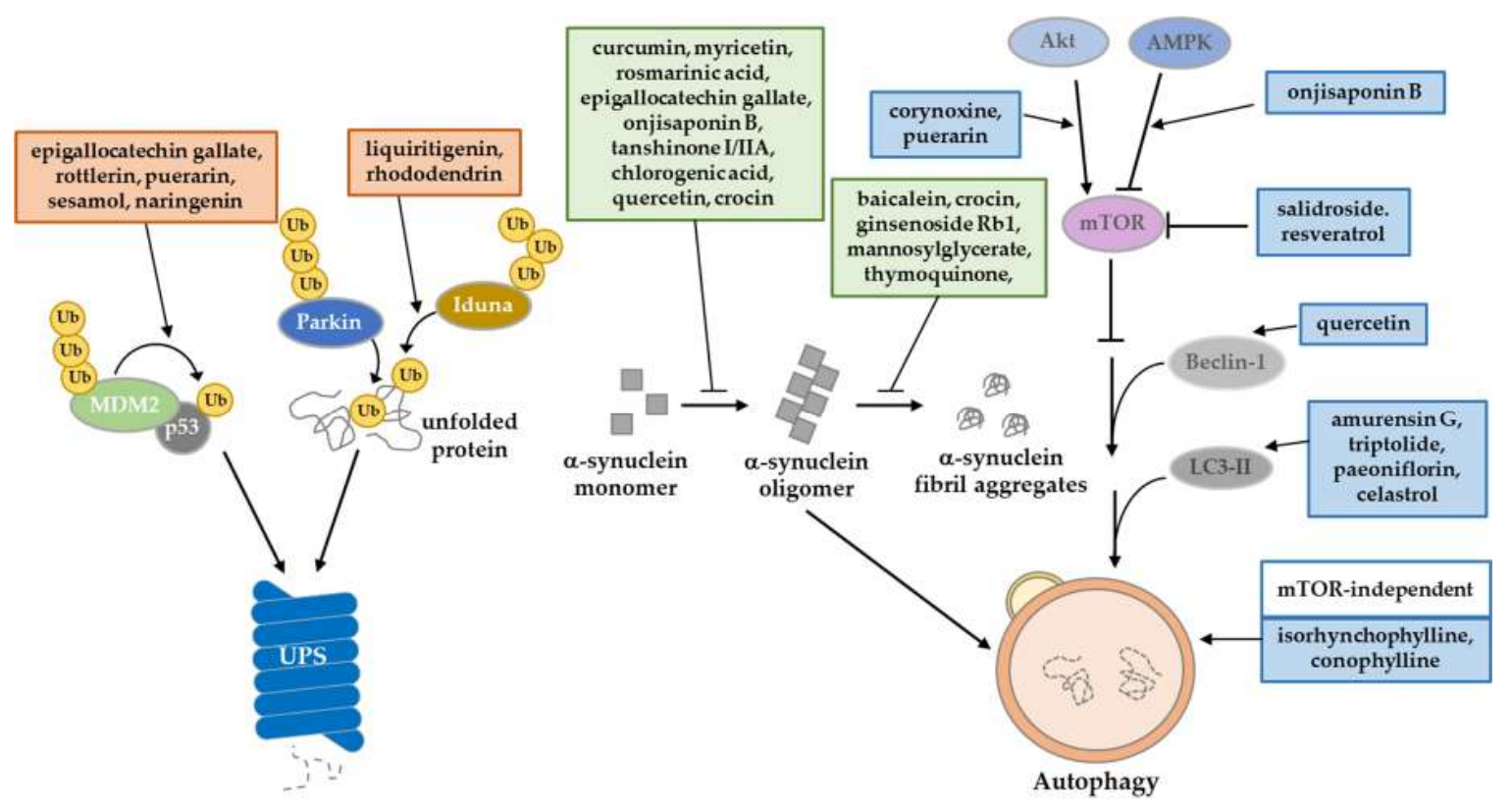

Figure 2. Summary of natural product regulation in proteostasis machinery. Natural products have a potential role to play in the amelioration of PD-induced proteostasis impairment. They regulate UPS through E3 ligase activity, increasing the autophagy-lysosome pathway, and inhibiting the posttranslational modifications of $\alpha$-synuclein.

\subsection{Regulation through the Ubiquitin-Proteasome System}

One of the protein degradation pathways is UPS. Proteins are polyubiquitinated by E3 ligase and finally cleared by the proteasome. Some studies have tried to restore the impaired activity of UPS in PD models by using natural compounds. Salidroside decreases the level of phosphorylated $\alpha$-synuclein (pSer129) by recovering proteasome activity in UPS-impaired PD models by 6-OHDA [145]. Because the E3 ligase, which catalyzes the polyubiquitination reaction, provides a key regulatory function in UPS, the regulation of its activity has been studied as a therapeutic strategy for PD. Some studies reported on the UPS-mediated regulation of p53, which is a key mediator of neuronal death in neurodegenerative diseases [156]. In PD patient brains, p53 is accumulated, and is involved in the degeneration of DA neurons [157]. Generally, MDM2, an E3 ligase, degrades p53, and could be activated by 553 in a negative feedback loop $[158,159]$. Upon cellular stress, including DNA damage, p53 becomes stable through its phosphorylation, mainly at the Ser-15 and -37 residues $[160,161]$. Due to its modification, the phosphorylated p53 destabilizes MDM2 and finally disorganizes the UPS function, leading to the aberrant protein accumulation. Some polyphenols, including flavonoids and lignans, have been reported to exhibit protective effect on impaired UPS regulating p53. Epigallocatechin gallate, rottlerin [62], puerarin [71], sesamol, and naringenin [59] inhibit the aberrant accumulation of p53 by recovering MDM2-mediated UPS, thereby suppressing p53-dependent cell death in PD models [62,71]. On the other hand, Parkin has an E3 ligase function, and its regulation has been investigated [162]. However, regulating Parkin activity through natural products is still under investigation. Another E3 ligase, IDUNA (RNF146), has PAR-dependent E3 ligase activity [163]. It protects against programmed cell death (called parthanatos) through proteasomal degradation. Recent studies have discovered that 
the natural products liquiritigenin and rhododendrin provide a neuroprotective effect in 6-OHDA PD models by inducing IDUNA activity. Both products bind to estrogen receptor- $\beta$ stimulating transcription of IDUNA [97,164].

\subsection{Regulation through the Autophagy-Lysosomal Pathway}

Another major protein degradation pathway is autophagy. It is a kind of pro-survival pathway, which clears misfolded or damaged proteins that cannot be degraded by unfolded protein response. Several toxin-induced PD models have been used to simulate the epidemiology of PD. Through exogenous toxins, ER stress evoked from increased ROS generation and decreased ATP synthesis can directly impair mitochondrial respiratory complex I [165]. Many studies have reported natural products that can treat these impaired mitochondrial environments by increasing autophagy flux and targeting specific mechanisms. A well-known natural product, quercetin, is an autophagy enhancer that plays a protective role in response to ER stress in rotenone-induced PD rat models. Quercetin treatment ameliorates DNA fragmentation and decreases beclin-1 levels [74]. Triptolide [68], Amurensin G [102] and celastrol [69] induces autophagy by activating LC3-II upregulation and clears $\alpha$-synuclein in vitro and in vivo PD models. Some studies have reported that natural products can elevate autophagic activity through the modulation of AKT/AMPK/mTOR signaling. An oxindole alkaloid, corynoxine, has been described as an autophagy inducer. Chen et al. (2014) suggested that corynoxine-induced autophagy can clear $\alpha$-synuclein through the Akt/mTOR pathway in neuronal cells and a Drosophila model [139]. Furthermore, Chen et al. (2017) introduced a model of corynoxine-induced neuronal autophagy. They established a network-based algorithm of in silico kinome activity profiling, and predict phosphoproteomic data. They then suggested that corynoxine-induced autophagy could clear $\alpha$-synuclein regulated by MAP2K2 and PLK1 kinase activity [166]. Onjisaponin B derived from Radix Polygalae was reported to have regulatory function of autophagy, enhancing autophagy flux by the AMPK/mTOR signaling pathway and finally removing $\alpha$-synuclein A53T mutant proteins [86].

\subsection{Inhibition of Protein Aggregation Formation}

The most frequently described protein in the pathology of PD is $\alpha$-synuclein. Aggregates of $\alpha$-synuclein can be toxic in cellular environments and can lead to PD [167]. Once $\alpha$-synuclein forms a fibril structure, it cannot be easily degraded through the protein degradation pathway. Inhibition of the formation of $\alpha$-synuclein aggregates is therefore a promising therapeutic strategy. Some studies have reported novel natural products that control $\alpha$-synuclein oligomerization. In particular, the polyphenol family has demonstrated an ability to directly or indirectly inhibit $\alpha$-synuclein oligomerization. Curcumin is a well-known antioxidant that can increase the solubility of the $\alpha$-synuclein form of monomers in catecholaminergic cell lines and in vivo models, thereby inhibiting oligomerization [168-171]. Pretreatment of rosmarinic acid inhibits reduction in the mitochondrial membrane potential and $\alpha$-synuclein aggregation through its iron-chelating activity in an MPTP-induced PD model [110]. In addition, myricetin can inhibit $\alpha$-synuclein oligomerization by directly binding to the $\alpha$-synuclein $\mathrm{N}$-terminal region in vitro [90]. Tanshinone I and tanshinone IIA decreased the formation of $\alpha$-synuclein oligomers [65]. Ginsenoside Rb1 dissociates $\alpha$-synuclein fibrillation through directly binding to $\alpha$-synuclein oligomers [88]. Tea polyphenols have been shown to protect DA neurons against PD in mice models. Additionally, their therapeutic effects have been reproduced in an MPTP-induced monkey PD model that prevents $\alpha$-synuclein oligomerization [172].

\section{Conclusions and Future Prospects}

In this review, we discussed the neuroprotective effects of lead compounds from natural products on mitochondrial quality control and proteostasis in experimental PD models. Unlike synthetic drugs that target only single molecules, some polyphenols, terpenes, and saponins have multiple and overlapped targets in other neurodegenerative diseases, including Alzheimer's disease as well as PD [173-175]. Natural compounds may serve as preventive supplements for age-related neurodegenerative diseases, 
and can be applied in combinatorial treatments to improve the quality of life of patients. Natural compounds have been widely tested in $\alpha$-synuclein- or neurotoxin-induced PD models. However, studies testing natural compounds for therapeutic purposes may have a limitation in terms of the differences of experimental design such as the quality of the extracts and the forms of dosage [176]. This could significantly affect the efficacy and toxicity of the natural compounds tested in each setting. Thus, it is necessary to organize the design of tests of natural compounds in PD models. The main limitation is the unclear therapeutic mechanism of natural compounds. These lead compounds can be adopted to design synthetic derivatives, but intensive study is required for further drug development.

Although the bioavailability of the compounds from natural products is limited, they can be easily obtained from herbs, fruits, and marine organisms, and their intake is relatively safe, particularly via foods. Some extracts allow for the continuous absorption of multiple compounds at low doses over a lifetime, potentially evoking hormesis signaling, which may extend lifespans. Thus, further study is necessary.

Author Contributions: All authors contributed to researching the literature and writing the article.

Funding: This work was supported by DGIST R\&D and the Basic Science Research Program through the National Research Foundation of Korea (NRF), funded by the Ministry of Science and ICT (MSIT) Y.-I.L. (18-LC-01, 19-BT-01) and J.L. (18-LC-01, 2017R1A2B4006200). J.L. also received funding from the Korean Institute of Oriental Medicine (KIOM), provided by the MSIT (KSN1812160).

Conflicts of Interest: The authors declare no conflict of interest.

\section{References}

1. Tysnes, O.B.; Storstein, A. Epidemiology of Parkinson's disease. J. Neural Transm. (Vienna) 2017, 124, 901-905. [CrossRef] [PubMed]

2. Kowal, S.L.; Dall, T.M.; Chakrabarti, R.; Storm, M.V.; Jain, A. The current and projected economic burden of Parkinson's disease in the United States. Mov. Disord. 2013, 28, 311-318. [CrossRef] [PubMed]

3. Economic Burden and Future Impact of Parkinson's Disease. Available online: https://www.michaeljfox.org/ publication/parkinsons-disease-economic-burden-patients-families-and-federal-government-52-billion (accessed on 1 August 2019).

4. Marsot, A.; Guilhaumou, R.; Azulay, J.P.; Blin, O. Levodopa in Parkinson's Disease: A Review of Population Pharmacokinetics/Pharmacodynamics Analysis. J. Pharm. Pharm. Sci. 2017, 20, 226-238. [CrossRef] [PubMed]

5. Huynh, T. The Parkinson's disease market. Nat. Rev. Drug Discov. 2011, 10, 571-572. [CrossRef]

6. Fearnley, J.M.; Lees, A.J. Ageing and Parkinson's disease: Substantia nigra regional selectivity. Brain 1991, 114 Pt 5, 2283-2301. [CrossRef]

7. Braak, H.; Del Tredici, K.; Rub, U.; de Vos, R.A.; Jansen Steur, E.N.; Braak, E. Staging of brain pathology related to sporadic Parkinson's disease. Neurobiol. Aging 2003, 24, 197-211. [CrossRef]

8. Dijkstra, A.A.; Voorn, P.; Berendse, H.W.; Groenewegen, H.J.; Netherlands Brain, B.; Rozemuller, A.J.; van de Berg, W.D. Stage-dependent nigral neuronal loss in incidental Lewy body and Parkinson's disease. Mov. Disord. 2014, 29, 1244-1251. [CrossRef]

9. Surmeier, D.J.; Obeso, J.A.; Halliday, G.M. Selective neuronal vulnerability in Parkinson disease. Nat. Rev. Neurosci. 2017, 18, 101-113. [CrossRef]

10. Poewe, W.; Seppi, K.; Tanner, C.M.; Halliday, G.M.; Brundin, P.; Volkmann, J.; Schrag, A.E.; Lang, A.E. Parkinson disease. Nat. Rev. Dis. Primers 2017, 3, 17013. [CrossRef]

11. Pickrell, A.M.; Youle, R.J. The roles of PINK1, parkin, and mitochondrial fidelity in Parkinson's disease. Neuron 2015, 85, 257-273. [CrossRef]

12. Truban, D.; Hou, X.; Caulfield, T.R.; Fiesel, F.C.; Springer, W. PINK1, Parkin, and Mitochondrial Quality Control: What can we Learn about Parkinson's Disease Pathobiology? J. Parkinsons Dis. 2017, 7, 13-29. [CrossRef] [PubMed]

13. Guzman, J.N.; Sanchez-Padilla, J.; Wokosin, D.; Kondapalli, J.; Ilijic, E.; Schumacker, P.T.; Surmeier, D.J. Oxidant stress evoked by pacemaking in dopaminergic neurons is attenuated by DJ-1. Nature 2010, 468, 696-700. [CrossRef] [PubMed] 
14. Di Nottia, M.; Masciullo, M.; Verrigni, D.; Petrillo, S.; Modoni, A.; Rizzo, V.; Di Giuda, D.; Rizza, T.; Niceta, M.; Torraco, A.; et al. DJ-1 modulates mitochondrial response to oxidative stress: Clues from a novel diagnosis of PARK7. Clin. Genet. 2017, 92, 18-25. [CrossRef] [PubMed]

15. Bonifati, V.; Rizzu, P.; van Baren, M.J.; Schaap, O.; Breedveld, G.J.; Krieger, E.; Dekker, M.C.; Squitieri, F.; Ibanez, P.; Joosse, M.; et al. Mutations in the DJ-1 gene associated with autosomal recessive early-onset parkinsonism. Science 2003, 299, 256-259. [CrossRef] [PubMed]

16. Janetzky, B.; Hauck, S.; Youdim, M.B.; Riederer, P.; Jellinger, K.; Pantucek, F.; Zochling, R.; Boissl, K.W.; Reichmann, H. Unaltered aconitase activity, but decreased complex I activity in substantia nigra pars compacta of patients with Parkinson's disease. Neurosci. Lett. 1994, 169, 126-128. [CrossRef]

17. Langston, J.W.; Ballard, P.; Tetrud, J.W.; Irwin, I. Chronic Parkinsonism in humans due to a product of meperidine-analog synthesis. Science 1983, 219, 979-980. [CrossRef] [PubMed]

18. Goldman, S.M. Environmental toxins and Parkinson's disease. Annu. Rev. Pharmacol. Toxicol. 2014, 54, 141-164. [CrossRef]

19. Park, J.S.; Davis, R.L.; Sue, C.M. Mitochondrial Dysfunction in Parkinson's Disease: New Mechanistic Insights and Therapeutic Perspectives. Curr. Neurol. Neurosci. Rep. 2018, 18, 21. [CrossRef]

20. Knott, A.B.; Perkins, G.; Schwarzenbacher, R.; Bossy-Wetzel, E. Mitochondrial fragmentation in neurodegeneration. Nat. Rev. Neurosci. 2008, 9, 505-518. [CrossRef]

21. Cassidy-Stone, A.; Chipuk, J.E.; Ingerman, E.; Song, C.; Yoo, C.; Kuwana, T.; Kurth, M.J.; Shaw, J.T.; Hinshaw, J.E.; Green, D.R.; et al. Chemical inhibition of the mitochondrial division dynamin reveals its role in Bax/Bak-dependent mitochondrial outer membrane permeabilization. Dev. Cell 2008, 14, 193-204. [CrossRef]

22. Rappold, P.M.; Cui, M.; Grima, J.C.; Fan, R.Z.; de Mesy-Bentley, K.L.; Chen, L.; Zhuang, X.; Bowers, W.J.; Tieu, K. Drp1 inhibition attenuates neurotoxicity and dopamine release deficits in vivo. Nat. Commun. 2014, 5, 5244. [CrossRef] [PubMed]

23. Filichia, E.; Hoffer, B.; Qi, X.; Luo, Y. Inhibition of Drp1 mitochondrial translocation provides neural protection in dopaminergic system in a Parkinson's disease model induced by MPTP. Sci. Rep. 2016, 6, 32656. [CrossRef] [PubMed]

24. Zheng, B.; Liao, Z.; Locascio, J.J.; Lesniak, K.A.; Roderick, S.S.; Watt, M.L.; Eklund, A.C.; Zhang-James, Y.; Kim, P.D.; Hauser, M.A.; et al. PGC-1alpha, a potential therapeutic target for early intervention in Parkinson's disease. Sci. Transl. Med. 2010, 2, 52ra73. [CrossRef] [PubMed]

25. Eschbach, J.; von Einem, B.; Muller, K.; Bayer, H.; Scheffold, A.; Morrison, B.E.; Rudolph, K.L.; Thal, D.R.; Witting, A.; Weydt, P.; et al. Mutual exacerbation of peroxisome proliferator-activated receptor gamma coactivator 1alpha deregulation and alpha-synuclein oligomerization. Ann. Neurol. 2015, 77, 15-32. [CrossRef] [PubMed]

26. Bian, M.; Liu, J.; Hong, X.; Yu, M.; Huang, Y.; Sheng, Z.; Fei, J.; Huang, F. Overexpression of parkin ameliorates dopaminergic neurodegeneration induced by 1- methyl-4-phenyl-1,2,3,6-tetrahydropyridine in mice. PLoS ONE 2012, 7, e39953. [CrossRef]

27. Melki, R. Role of Different Alpha-Synuclein Strains in Synucleinopathies, Similarities with other Neurodegenerative Diseases. J. Parkinsons Dis. 2015, 5, 217-227. [CrossRef]

28. Ludtmann, M.H.R.; Angelova, P.R.; Horrocks, M.H.; Choi, M.L.; Rodrigues, M.; Baev, A.Y.; Berezhnov, A.V.; Yao, Z.; Little, D.; Banushi, B.; et al. alpha-synuclein oligomers interact with ATP synthase and open the permeability transition pore in Parkinson's disease. Nat. Commun. 2018, 9, 2293. [CrossRef]

29. Ebrahimi-Fakhari, D.; Cantuti-Castelvetri, I.; Fan, Z.; Rockenstein, E.; Masliah, E.; Hyman, B.T.; McLean, P.J.; Unni, V.K. Distinct roles in vivo for the ubiquitin-proteasome system and the autophagy-lysosomal pathway in the degradation of alpha-synuclein. J. Neurosci. 2011, 31, 14508-14520. [CrossRef]

30. Webb, J.L.; Ravikumar, B.; Atkins, J.; Skepper, J.N.; Rubinsztein, D.C. Alpha-Synuclein is degraded by both autophagy and the proteasome. J. Biol. Chem. 2003, 278, 25009-25013. [CrossRef]

31. Liu, K.; Shi, N.; Sun, Y.; Zhang, T.; Sun, X. Therapeutic effects of rapamycin on MPTP-induced Parkinsonism in mice. Neurochem. Res. 2013, 38, 201-207. [CrossRef]

32. Da Costa, C.A.; Sunyach, C.; Giaime, E.; West, A.; Corti, O.; Brice, A.; Safe, S.; Abou-Sleiman, P.M.; Wood, N.W.; Takahashi, H.; et al. Transcriptional repression of $\mathrm{p} 53$ by parkin and impairment by mutations associated with autosomal recessive juvenile Parkinson's disease. Nat. Cell Biol. 2009, 11, 1370-1375. [CrossRef] [PubMed] 
33. Shin, J.H.; Ko, H.S.; Kang, H.; Lee, Y.; Lee, Y.I.; Pletinkova, O.; Troconso, J.C.; Dawson, V.L.; Dawson, T.M. PARIS (ZNF746) repression of PGC-1alpha contributes to neurodegeneration in Parkinson's disease. Cell 2011, 144, 689-702. [CrossRef] [PubMed]

34. Lee, Y.; Karuppagounder, S.S.; Shin, J.H.; Lee, Y.I.; Ko, H.S.; Swing, D.; Jiang, H.; Kang, S.U.; Lee, B.D.; Kang, H.C.; et al. Parthanatos mediates AIMP2-activated age-dependent dopaminergic neuronal loss. Nat. Neurosci. 2013, 16, 1392-1400. [CrossRef] [PubMed]

35. Kam, T.I.; Mao, X.; Park, H.; Chou, S.C.; Karuppagounder, S.S.; Umanah, G.E.; Yun, S.P.; Brahmachari, S.; Panicker, N.; Chen, R.; et al. Poly(ADP-ribose) drives pathologic alpha-synuclein neurodegeneration in Parkinson's disease. Science 2018, 362, eaat8407. [CrossRef] [PubMed]

36. Lin, M.T.; Beal, M.F. Mitochondrial dysfunction and oxidative stress in neurodegenerative diseases. Nature 2006, 443, 787-795. [CrossRef]

37. Collins, Y.; Chouchani, E.T.; James, A.M.; Menger, K.E.; Cocheme, H.M.; Murphy, M.P. Mitochondrial redox signalling at a glance. J. Cell Sci. 2012, 125, 801-806. [CrossRef]

38. Puspita, L.; Chung, S.Y.; Shim, J.W. Oxidative stress and cellular pathologies in Parkinson's disease. Mol. Brain 2017, 10, 53. [CrossRef]

39. Gazaryan, I.G.; Thomas, B. The status of Nrf2-based therapeutics: Current perspectives and future prospects. Neural Regen. Res. 2016, 11, 1708-1711. [CrossRef]

40. Zhang, Z.; Cui, W.; Li, G.; Yuan, S.; Xu, D.; Hoi, M.P.; Lin, Z.; Dou, J.; Han, Y.; Lee, S.M. Baicalein protects against 6-OHDA-induced neurotoxicity through activation of Keap1/Nrf2/HO-1 and involving PKCalpha and PI3K/AKT signaling pathways. J. Agric. Food Chem. 2012, 60, 8171-8182. [CrossRef]

41. Wruck, C.J.; Claussen, M.; Fuhrmann, G.; Romer, L.; Schulz, A.; Pufe, T.; Waetzig, V.; Peipp, M.; Herdegen, T.; Gotz, M.E. Luteolin protects rat PC12 and C6 cells against MPP+ induced toxicity via an ERK dependent Keap1-Nrf2-ARE pathway. J. Neural Transm. Suppl. 2007, 72, 57-67.

42. Lou, H.; Jing, X.; Wei, X.; Shi, H.; Ren, D.; Zhang, X. Naringenin protects against 6-OHDA-induced neurotoxicity via activation of the Nrf2/ARE signaling pathway. Neuropharmacology 2014, 79, 380-388. [CrossRef] [PubMed]

43. Li, R.; Liang, T.; Xu, L.; Zheng, N.; Zhang, K.; Duan, X. Puerarin attenuates neuronal degeneration in the substantia nigra of 6-OHDA-lesioned rats through regulating BDNF expression and activating the Nrf2/ARE signaling pathway. Brain Res. 2013, 1523, 1-9. [CrossRef] [PubMed]

44. Wu, H.C.; Hu, Q.L.; Zhang, S.J.; Wang, Y.M.; Jin, Z.K.; Lv, L.F.; Zhang, S.; Liu, Z.L.; Wu, H.L.; Cheng, O.M. Neuroprotective effects of genistein on SH-SY5Y cells overexpressing A53T mutant alpha-synuclein. Neural Regen. Res. 2018, 13, 1375-1383. [CrossRef] [PubMed]

45. Jang, Y.; Choo, H.; Lee, M.J.; Han, J.; Kim, S.J.; Ju, X.; Cui, J.; Lee, Y.L.; Ryu, M.J.; Oh, E.S.; et al. Auraptene Mitigates Parkinson's Disease-Like Behavior by Protecting Inhibition of Mitochondrial Respiration and Scavenging Reactive Oxygen Species. Int. J. Mol. Sci. 2019, 20, 3409. [CrossRef] [PubMed]

46. Gaballah, H.H.; Zakaria, S.S.; Elbatsh, M.M.; Tahoon, N.M. Modulatory effects of resveratrol on endoplasmic reticulum stress-associated apoptosis and oxido-inflammatory markers in a rat model of rotenone-induced Parkinson's disease. Chem. Biol. Interact. 2016, 251, 10-16. [CrossRef]

47. Feng, C.W.; Hung, H.C.; Huang, S.Y.; Chen, C.H.; Chen, Y.R.; Chen, C.Y.; Yang, S.N.; Wang, H.D.; Sung, P.J.; Sheu, J.H.; et al. Neuroprotective Effect of the Marine-Derived Compound 11-Dehydrosinulariolide through DJ-1-Related Pathway in In Vitro and In Vivo Models of Parkinson's Disease. Mar. Drugs 2016, 14, 187. [CrossRef]

48. Jing, X.; Wei, X.; Ren, M.; Wang, L.; Zhang, X.; Lou, H. Neuroprotective Effects of Tanshinone I Against 6-OHDA-Induced Oxidative Stress in Cellular and Mouse Model of Parkinson's Disease Through Upregulating Nrf2. Neurochem. Res. 2016, 41, 779-786. [CrossRef]

49. Zhang, X.S.; Ha, S.; Wang, X.L.; Shi, Y.L.; Duan, S.S.; Li, Z.A. Tanshinone IIA protects dopaminergic neurons against 6-hydroxydopamine-induced neurotoxicity through miR-153/NF-E2-related factor 2/antioxidant response element signaling pathway. Neuroscience 2015, 303, 489-502. [CrossRef]

50. Ye, Q.; Huang, B.; Zhang, X.; Zhu, Y.; Chen, X. Astaxanthin protects against MPP(+)-induced oxidative stress in PC12 cells via the HO-1/NOX2 axis. BMC Neurosci. 2012, 13, 156. [CrossRef]

51. Meng, X.B.; Sun, G.B.; Wang, M.; Sun, J.; Qin, M.; Sun, X.B. P90RSK and Nrf2 Activation via MEK1/2-ERK1/2 Pathways Mediated by Notoginsenoside R2 to Prevent 6-Hydroxydopamine-Induced Apoptotic Death in SH-SY5Y Cells. Evid. Based Complement. Alternat. Med. 2013, 2013, 971712. [CrossRef] 
52. Gonzalez-Burgos, E.; Fernandez-Moriano, C.; Lozano, R.; Iglesias, I.; Gomez-Serranillos, M.P. Ginsenosides $\mathrm{Rd}$ and $\mathrm{Re}$ co-treatments improve rotenone-induced oxidative stress and mitochondrial impairment in SH-SY5Y neuroblastoma cells. Food Chem. Toxicol. 2017, 109, 38-47. [CrossRef] [PubMed]

53. Michel, H.E.; Tadros, M.G.; Esmat, A.; Khalifa, A.E.; Abdel-Tawab, A.M. Tetramethylpyrazine Ameliorates Rotenone-Induced Parkinson's Disease in Rats: Involvement of Its Anti-Inflammatory and Anti-Apoptotic Actions. Mol. Neurobiol. 2017, 54, 4866-4878. [CrossRef] [PubMed]

54. Zhang, L.; Hao, J.; Zheng, Y.; Su, R.; Liao, Y.; Gong, X.; Liu, L.; Wang, X. Fucoidan Protects Dopaminergic Neurons by Enhancing the Mitochondrial Function in a Rotenone-induced Rat Model of Parkinson's Disease. Aging Dis. 2018, 9, 590-604. [CrossRef] [PubMed]

55. Jiang, G.; Hu, Y.; Liu, L.; Cai, J.; Peng, C.; Li, Q. Gastrodin protects against MPP(+)-induced oxidative stress by up regulates heme oxygenase-1 expression through p38 MAPK/Nrf2 pathway in human dopaminergic cells. Neurochem. Int. 2014, 75, 79-88. [CrossRef]

56. Chong, C.M.; Zhou, Z.Y.; Razmovski-Naumovski, V.; Cui, G.Z.; Zhang, L.Q.; Sa, F.; Hoi, P.M.; Chan, K.; Lee, S.M. Danshensu protects against 6-hydroxydopamine-induced damage of PC12 cells in vitro and dopaminergic neurons in zebrafish. Neurosci. Lett. 2013, 543, 121-125. [CrossRef]

57. Li, R.; Wang, S.; Li, T.; Wu, L.; Fang, Y.; Feng, Y.; Zhang, L.; Chen, J.; Wang, X. Salidroside Protects Dopaminergic Neurons by Preserving Complex I Activity via DJ-1/Nrf2-Mediated Antioxidant Pathway. Parkinsons Dis. 2019, 2019, 6073496. [CrossRef]

58. Biosa, A.; Sandrelli, F.; Beltramini, M.; Greggio, E.; Bubacco, L.; Bisaglia, M. Recent findings on the physiological function of DJ-1: Beyond Parkinson's disease. Neurobiol. Dis. 2017, 108, 65-72. [CrossRef]

59. Sonia Angeline, M.; Sarkar, A.; Anand, K.; Ambasta, R.K.; Kumar, P. Sesamol and naringenin reverse the effect of rotenone-induced PD rat model. Neuroscience 2013, 254, 379-394. [CrossRef]

60. Magalingam, K.B.; Radhakrishnan, A.; Ramdas, P.; Haleagrahara, N. Quercetin glycosides induced neuroprotection by changes in the gene expression in a cellular model of Parkinson's disease. J. Mol. Neurosci. 2015, 55, 609-617. [CrossRef]

61. Ye, Q.; Ye, L.; Xu, X.; Huang, B.; Zhang, X.; Zhu, Y.; Chen, X. Epigallocatechin-3-gallate suppresses 1-methyl-4-phenyl-pyridine-induced oxidative stress in PC12 cells via the SIRT1/PGC-1alpha signaling pathway. BMC Complement. Altern. Med. 2012, 12, 82. [CrossRef]

62. Lee, S.J.; Kim, D.C.; Choi, B.H.; Ha, H.; Kim, K.T. Regulation of p53 by activated protein kinase C-delta during nitric oxide-induced dopaminergic cell death. J. Biol. Chem. 2006, 281, 2215-2224. [CrossRef] [PubMed]

63. Patil, S.P.; Jain, P.D.; Sancheti, J.S.; Ghumatkar, P.J.; Tambe, R.; Sathaye, S. Neuroprotective and neurotrophic effects of Apigenin and Luteolin in MPTP induced parkinsonism in mice. Neuropharmacology 2014, 86, 192-202. [CrossRef] [PubMed]

64. Anusha, C.; Sumathi, T.; Joseph, L.D. Protective role of apigenin on rotenone induced rat model of Parkinson's disease: Suppression of neuroinflammation and oxidative stress mediated apoptosis. Chem. Biol. Interact. 2017, 269, 67-79. [CrossRef] [PubMed]

65. Ji, K.; Zhao, Y.; Yu, T.; Wang, Z.; Gong, H.; Yang, X.; Liu, Y.; Huang, K. Inhibition effects of tanshinone on the aggregation of alpha-synuclein. Food Funct. 2016, 7, 409-416. [CrossRef]

66. Zhu, M.; Rajamani, S.; Kaylor, J.; Han, S.; Zhou, F.; Fink, A.L. The flavonoid baicalein inhibits fibrillation of alpha-synuclein and disaggregates existing fibrils. J. Biol. Chem. 2004, 279, 26846-26857. [CrossRef]

67. Wu, Y.; Jiang, X.; Yang, K.; Xia, Y.; Cheng, S.; Tang, Q.; Bai, L.; Qiu, J.; Chen, C. Inhibition of alpha-Synuclein contributes to the ameliorative effects of dietary flavonoids luteolin on arsenite-induced apoptotic cell death in the dopaminergic PC12 cells. Toxicol. Mech. Methods 2017, 27, 598-608. [CrossRef]

68. Hu, G.; Gong, X.; Wang, L.; Liu, M.; Liu, Y.; Fu, X.; Wang, W.; Zhang, T.; Wang, X. Triptolide Promotes the Clearance of alpha-Synuclein by Enhancing Autophagy in Neuronal Cells. Mol. Neurobiol. 2017, 54, 2361-2372. [CrossRef]

69. Deng, Y.N.; Shi, J.; Liu, J.; Qu, Q.M. Celastrol protects human neuroblastoma SH-SY5Y cells from rotenone-induced injury through induction of autophagy. Neurochem. Int. 2013, 63, 1-9. [CrossRef]

70. Zhang, C.; Wang, R.; Liu, Z.; Bunker, E.; Lee, S.; Giuntini, M.; Chapnick, D.; Liu, X. The plant triterpenoid celastrol blocks PINK1-dependent mitophagy by disrupting PINK1's association with the mitochondrial protein TOM20. J. Biol. Chem. 2019, 294, 7472-7487. [CrossRef] 
71. Cheng, Y.F.; Zhu, G.Q.; Wang, M.; Cheng, H.; Zhou, A.; Wang, N.; Fang, N.; Wang, X.C.; Xiao, X.Q.; Chen, Z.W.; et al. Involvement of ubiquitin proteasome system in protective mechanisms of Puerarin to MPP(+)-elicited apoptosis. Neurosci. Res. 2009, 63, 52-58. [CrossRef]

72. Rai, S.N.; Yadav, S.K.; Singh, D.; Singh, S.P. Ursolic acid attenuates oxidative stress in nigrostriatal tissue and improves neurobehavioral activity in MPTP-induced Parkinsonian mouse model. J. Chem. Neuroanat. 2016, 71, 41-49. [CrossRef] [PubMed]

73. Ay, M.; Luo, J.; Langley, M.; Jin, H.; Anantharam, V.; Kanthasamy, A.; Kanthasamy, A.G. Molecular mechanisms underlying protective effects of quercetin against mitochondrial dysfunction and progressive dopaminergic neurodegeneration in cell culture and MitoPark transgenic mouse models of Parkinson's Disease. J. Neurochem. 2017, 141, 766-782. [CrossRef] [PubMed]

74. El-Horany, H.E.; El-Latif, R.N.; ElBatsh, M.M.; Emam, M.N. Ameliorative Effect of Quercetin on Neurochemical and Behavioral Deficits in Rotenone Rat Model of Parkinson's Disease: Modulating Autophagy (Quercetin on Experimental Parkinson's Disease). J. Biochem. Mol. Toxicol. 2016, 30, 360-369. [CrossRef]

75. Xu, C.L.; Wang, Q.Z.; Sun, L.M.; Li, X.M.; Deng, J.M.; Li, L.F.; Zhang, J.; Xu, R.; Ma, S.P. Asiaticoside: Attenuation of neurotoxicity induced by MPTP in a rat model of Parkinsonism via maintaining redox balance and up-regulating the ratio of Bcl-2/Bax. Pharmacol. Biochem. Behav. 2012, 100, 413-418. [CrossRef] [PubMed]

76. Elmazoglu, Z.; Ergin, V.; Sahin, E.; Kayhan, H.; Karasu, C. Oleuropein and rutin protect against 6-OHDA-induced neurotoxicity in PC12 cells through modulation of mitochondrial function and unfolded protein response. Interdiscip. Toxicol. 2017, 10, 129-141. [CrossRef]

77. Javed, H.; Azimullah, S.; Abul Khair, S.B.; Ojha, S.; Haque, M.E. Neuroprotective effect of nerolidol against neuroinflammation and oxidative stress induced by rotenone. BMC Neurosci. 2016, 17, 58. [CrossRef]

78. Liu, Y.; Chong, L.; Li, X.; Tang, P.; Liu, P.; Hou, C.; Zhang, X.; Li, R. Astragaloside IV rescues MPP(+)-induced mitochondrial dysfunction through upregulation of methionine sulfoxide reductase A. Exp. Ther Med. 2017, 14, 2650-2656. [CrossRef]

79. Liu, X.; Zhang, J.; Wang, S.; Qiu, J.; Yu, C. Astragaloside IV attenuates the H2O2-induced apoptosis of neuronal cells by inhibiting alpha-synuclein expression via the p38 MAPK pathway. Int. J. Mol. Med. 2017, 40, 1772-1780. [CrossRef]

80. Filomeni, G.; Graziani, I.; De Zio, D.; Dini, L.; Centonze, D.; Rotilio, G.; Ciriolo, M.R. Neuroprotection of kaempferol by autophagy in models of rotenone-mediated acute toxicity: Possible implications for Parkinson's disease. Neurobiol. Aging 2012, 33, 767-785. [CrossRef]

81. Li, S.; Pu, X.P. Neuroprotective effect of kaempferol against a 1-methyl-4-phenyl-1,2,3,6-tetrahydropyridineinduced mouse model of Parkinson's disease. Biol. Pharm. Bull. 2011, 34, 1291-1296. [CrossRef]

82. Wang, P.; Niu, L.; Gao, L.; Li, W.X.; Jia, D.; Wang, X.L.; Gao, G.D. Neuroprotective effect of gypenosides against oxidative injury in the substantia nigra of a mouse model of Parkinson's disease. J. Int. Med. Res. 2010, 38, 1084-1092. [CrossRef] [PubMed]

83. Hwang, C.K.; Chun, H.S. Isoliquiritigenin isolated from licorice Glycyrrhiza uralensis prevents 6-hydroxydopamine-induced apoptosis in dopaminergic neurons. Biosci. Biotechnol. Biochem. 2012, 76, 536-543. [CrossRef]

84. Zhang, C.; Li, C.; Chen, S.; Li, Z.; Ma, L.; Jia, X.; Wang, K.; Bao, J.; Liang, Y.; Chen, M.; et al. Hormetic effect of panaxatriol saponins confers neuroprotection in PC12 cells and zebrafish through PI3K/AKT/mTOR and AMPK/SIRT1/FOXO3 pathways. Sci. Rep. 2017, 7, 41082. [CrossRef]

85. Yu, L.; Wang, X.; Chen, H.; Yan, Z.; Wang, M.; Li, Y. Neurochemical and Behavior Deficits in Rats with Iron and Rotenone Co-treatment: Role of Redox Imbalance and Neuroprotection by Biochanin A. Front. Neurosci. 2017, 11, 657. [CrossRef] [PubMed]

86. Wu, A.G.; Wong, V.K.; Xu, S.W.; Chan, W.K.; Ng, C.I.; Liu, L.; Law, B.Y. Onjisaponin B derived from Radix Polygalae enhances autophagy and accelerates the degradation of mutant alpha-synuclein and huntingtin in PC-12 cells. Int. J. Mol. Sci. 2013, 14, 22618-22641. [CrossRef]

87. Antunes, M.S.; Goes, A.T.; Boeira, S.P.; Prigol, M.; Jesse, C.R. Protective effect of hesperidin in a model of Parkinson's disease induced by 6-hydroxydopamine in aged mice. Nutrition 2014, 30, 1415-1422. [CrossRef] [PubMed] 
88. Ardah, M.T.; Paleologou, K.E.; Lv, G.; Menon, S.A.; Abul Khair, S.B.; Lu, J.H.; Safieh-Garabedian, B.; Al-Hayani, A.A.; Eliezer, D.; Li, M.; et al. Ginsenoside Rb1 inhibits fibrillation and toxicity of alpha-synuclein and disaggregates preformed fibrils. Neurobiol. Dis. 2015, 74, 89-101. [CrossRef]

89. Zhang, Z.T.; Cao, X.B.; Xiong, N.; Wang, H.C.; Huang, J.S.; Sun, S.G.; Wang, T. Morin exerts neuroprotective actions in Parkinson disease models in vitro and in vivo. Acta Pharmacol. Sin. 2010, 31, 900-906. [CrossRef]

90. Takahashi, R.; Ono, K.; Takamura, Y.; Mizuguchi, M.; Ikeda, T.; Nishijo, H.; Yamada, M. Phenolic compounds prevent the oligomerization of alpha-synuclein and reduce synaptic toxicity. J. Neurochem. 2015, 134, 943-955. [CrossRef]

91. Zhang, K.; Ma, Z.; Wang, J.; Xie, A.; Xie, J. Myricetin attenuated MPP(+)-induced cytotoxicity by anti-oxidation and inhibition of MKK4 and JNK activation in MES23.5 cells. Neuropharmacology 2011, 61, 329-335. [CrossRef]

92. Ren, Z.X.; Zhao, Y.F.; Cao, T.; Zhen, X.C. Dihydromyricetin protects neurons in an MPTP-induced model of Parkinson's disease by suppressing glycogen synthase kinase-3 beta activity. Acta Pharmacol. Sin. 2016, 37, 1315-1324. [CrossRef] [PubMed]

93. Wu, J.Z.; Ardah, M.; Haikal, C.; Svanbergsson, A.; Diepenbroek, M.; Vaikath, N.N.; Li, W.; Wang, Z.Y.; Outeiro, T.F.; El-Agnaf, O.M.; et al. Dihydromyricetin and Salvianolic acid B inhibit alpha-synuclein aggregation and enhance chaperone-mediated autophagy. Transl. Neurodegener. 2019, 8, 18. [CrossRef] [PubMed]

94. Heng, Y.; Zhang, Q.S.; Mu, Z.; Hu, J.F.; Yuan, Y.H.; Chen, N.H. Ginsenoside Rg1 attenuates motor impairment and neuroinflammation in the MPTP-probenecid-induced parkinsonism mouse model by targeting alpha-synuclein abnormalities in the substantia nigra. Toxicol. Lett. 2016, 243, 7-21. [CrossRef] [PubMed]

95. Chen, X.C.; Zhou, Y.C.; Chen, Y.; Zhu, Y.G.; Fang, F.; Chen, L.M. Ginsenoside Rg1 reduces MPTP-induced substantia nigra neuron loss by suppressing oxidative stress. Acta Pharmacol. Sin. 2005, 26, 56-62. [CrossRef] [PubMed]

96. Baluchnejadmojarad, T.; Jamali-Raeufy, N.; Zabihnejad, S.; Rabiee, N.; Roghani, M. Troxerutin exerts neuroprotection in 6-hydroxydopamine lesion rat model of Parkinson's disease: Possible involvement of PI3K/ERbeta signaling. Eur. J. Pharmacol. 2017, 801, 72-78. [CrossRef]

97. Kim, H.; Ham, S.; Lee, J.Y.; Jo, A.; Lee, G.H.; Lee, Y.S.; Cho, M.; Shin, H.M.; Kim, D.; Pletnikova, O.; et al. Estrogen receptor activation contributes to RNF146 expression and neuroprotection in Parkinson's disease models. Oncotarget 2017, 8, 106721-106739. [CrossRef]

98. Li, X.M.; Zhang, X.J.; Dong, M.X. Isorhynchophylline Attenuates MPP(+)-Induced Apoptosis Through Endoplasmic Reticulum Stress- and Mitochondria-Dependent Pathways in PC12 Cells: Involvement of Antioxidant Activity. Neuromol. Med. 2017, 19, 480-492. [CrossRef]

99. Lu, J.H.; Tan, J.Q.; Durairajan, S.S.; Liu, L.F.; Zhang, Z.H.; Ma, L.; Shen, H.M.; Chan, H.Y.; Li, M. Isorhynchophylline, a natural alkaloid, promotes the degradation of alpha-synuclein in neuronal cells via inducing autophagy. Autophagy 2012, 8, 98-108. [CrossRef]

100. Sasazawa, Y.; Sato, N.; Umezawa, K.; Simizu, S. Conophylline protects cells in cellular models of neurodegenerative diseases by inducing mammalian target of rapamycin (mTOR)-independent autophagy. J. Biol. Chem. 2015, 290, 6168-6178. [CrossRef]

101. Molina-Jimenez, M.F.; Sanchez-Reus, M.I.; Andres, D.; Cascales, M.; Benedi, J. Neuroprotective effect of fraxetin and myricetin against rotenone-induced apoptosis in neuroblastoma cells. Brain Res. 2004, 1009, 9-16. [CrossRef]

102. Ryu, H.W.; Oh, W.K.; Jang, I.S.; Park, J. Amurensin G induces autophagy and attenuates cellular toxicities in a rotenone model of Parkinson's disease. Biochem. Biophys. Res. Commun. 2013, 433, 121-126. [CrossRef] [PubMed]

103. Zhao, D.L.; Zou, L.B.; Lin, S.; Shi, J.G.; Zhu, H.B. Anti-apoptotic effect of esculin on dopamine-induced cytotoxicity in the human neuroblastoma SH-SY5Y cell line. Neuropharmacology 2007, 53, 724-732. [CrossRef] [PubMed]

104. Yurchenko, E.A.; Menchinskaya, E.S.; Pislyagin, E.A.; Trinh, P.T.H.; Ivanets, E.V.; Smetanina, O.F.; Yurchenko, A.N. Neuroprotective Activity of Some Marine Fungal Metabolites in the 6-Hydroxydopaminand Paraquat-Induced Parkinson's Disease Models. Mar. Drugs 2018, 16, 457. [CrossRef] [PubMed]

105. Angeles, D.C.; Ho, P.; Dymock, B.W.; Lim, K.L.; Zhou, Z.D.; Tan, E.K. Antioxidants inhibit neuronal toxicity in Parkinson's disease-linked LRRK2. Ann. Clin. Transl. Neurol. 2016, 3, 288-294. [CrossRef] [PubMed] 
106. Shan, S.; Tian, L.; Fang, R. Chlorogenic Acid Exerts Beneficial Effects in 6-Hydroxydopamine-Induced Neurotoxicity by Inhibition of Endoplasmic Reticulum Stress. Med. Sci. Monit. 2019, 25, 453-459. [CrossRef]

107. Teraoka, M.; Nakaso, K.; Kusumoto, C.; Katano, S.; Tajima, N.; Yamashita, A.; Zushi, T.; Ito, S.; Matsura, T. Cytoprotective effect of chlorogenic acid against alpha-synuclein-related toxicity in catecholaminergic PC12 cells. J. Clin. Biochem. Nutr. 2012, 51, 122-127. [CrossRef]

108. Chen, J.; Tang, X.Q.; Zhi, J.L.; Cui, Y.; Yu, H.M.; Tang, E.H.; Sun, S.N.; Feng, J.Q.; Chen, P.X. Curcumin protects PC12 cells against 1-methyl-4-phenylpyridinium ion-induced apoptosis by bcl-2-mitochondria-ROS-iNOS pathway. Apoptosis 2006, 11, 943-953. [CrossRef]

109. Camilleri, A.; Zarb, C.; Caruana, M.; Ostermeier, U.; Ghio, S.; Hogen, T.; Schmidt, F.; Giese, A.; Vassallo, N. Mitochondrial membrane permeabilisation by amyloid aggregates and protection by polyphenols. Biochim. Biophys. Acta 2013, 1828, 2532-2543. [CrossRef]

110. Qu, L.; Xu, H.; Jia, W.; Jiang, H.; Xie, J. Rosmarinic acid protects against MPTP-induced toxicity and inhibits iron-induced alpha-synuclein aggregation. Neuropharmacology 2019, 144, 291-300. [CrossRef]

111. Lin, K.L.; Lin, K.J.; Wang, P.W.; Chuang, J.H.; Lin, H.Y.; Chen, S.D.; Chuang, Y.C.; Huang, S.T.; Tiao, M.M.; Chen, J.B.; et al. Resveratrol provides neuroprotective effects through modulation of mitochondrial dynamics and ERK1/2 regulated autophagy. Free Radic. Res. 2018, 52, 1371-1386. [CrossRef]

112. Peng, K.; Tao, Y.; Zhang, J.; Wang, J.; Ye, F.; Dan, G.; Zhao, Y.; Cai, Y.; Zhao, J.; Wu, Q.; et al. Resveratrol Regulates Mitochondrial Biogenesis and Fission/Fusion to Attenuate Rotenone-Induced Neurotoxicity. Oxid. Med. Cell Longev. 2016, 2016, 6705621. [CrossRef] [PubMed]

113. Mudo, G.; Makela, J.; Di Liberto, V.; Tselykh, T.V.; Olivieri, M.; Piepponen, P.; Eriksson, O.; Malkia, A.; Bonomo, A.; Kairisalo, M.; et al. Transgenic expression and activation of PGC-1alpha protect dopaminergic neurons in the MPTP mouse model of Parkinson's disease. Cell Mol. Life Sci. 2012, 69, 1153-1165. [CrossRef] [PubMed]

114. Faria, C.; Jorge, C.D.; Borges, N.; Tenreiro, S.; Outeiro, T.F.; Santos, H. Inhibition of formation of alpha-synuclein inclusions by mannosylglycerate in a yeast model of Parkinson's disease. Biochim. Biophys. Acta 2013, 1830, 4065-4072. [CrossRef] [PubMed]

115. Zhang, L.; Huang, L.; Li, X.; Liu, C.; Sun, X.; Wu, L.; Li, T.; Yang, H.; Chen, J. Potential molecular mechanisms mediating the protective effects of tetrahydroxystilbene glucoside on MPP(+)-induced PC12 cell apoptosis. Mol. Cell Biochem. 2017, 436, 203-213. [CrossRef] [PubMed]

116. Zhang, R.; Sun, F.; Zhang, L.; Sun, X.; Li, L. Tetrahydroxystilbene glucoside inhibits alpha-synuclein aggregation and apoptosis in A53T alpha-synuclein-transfected cells exposed to $\mathrm{MPP}^{+}$. Can. J. Physiol. Pharmacol. 2017, 95, 750-758. [CrossRef] [PubMed]

117. Olatunji, O.J.; Feng, Y.; Olatunji, O.O.; Tang, J.; Ouyang, Z.; Su, Z. Cordycepin protects PC12 cells against 6-hydroxydopamine induced neurotoxicity via its antioxidant properties. Biomed. Pharmacother. 2016, 81, 7-14. [CrossRef] [PubMed]

118. Zhang, H.A.; Gao, M.; Zhang, L.; Zhao, Y.; Shi, L.L.; Chen, B.N.; Wang, Y.H.; Wang, S.B.; Du, G.H. Salvianolic acid A protects human SH-SY5Y neuroblastoma cells against $\mathrm{H}(2) \mathrm{O}(2)$-induced injury by increasing stress tolerance ability. Biochem. Biophys. Res. Commun. 2012, 421, 479-483. [CrossRef]

119. Wang, X.J.; Xu, J.X. Salvianic acid A protects human neuroblastoma SH-SY5Y cells against MPP+-induced cytotoxicity. Neurosci. Res. 2005, 51, 129-138. [CrossRef]

120. Wang, J.; Liu, H.; Jin, W.; Zhang, H.; Zhang, Q. Structure-activity relationship of sulfated hetero/galactofucan polysaccharides on dopaminergic neuron. Int. J. Biol. Macromol. 2016, 82, 878-883. [CrossRef]

121. Tian, L.L.; Wang, X.J.; Sun, Y.N.; Li, C.R.; Xing, Y.L.; Zhao, H.B.; Duan, M.; Zhou, Z.; Wang, S.Q. Salvianolic acid B, an antioxidant from Salvia miltiorrhiza, prevents 6-hydroxydopamine induced apoptosis in SH-SY5Y cells. Int. J. Biochem. Cell Biol. 2008, 40, 409-422. [CrossRef]

122. Chen, Y.; Zhang, D.Q.; Liao, Z.; Wang, B.; Gong, S.; Wang, C.; Zhang, M.Z.; Wang, G.H.; Cai, H.; Liao, F.F.; et al. Anti-oxidant polydatin (piceid) protects against substantia nigral motor degeneration in multiple rodent models of Parkinson's disease. Mol. Neurodegener. 2015, 10, 4. [CrossRef] [PubMed]

123. Han, Y.S.; Lee, J.H.; Lee, S.H. Fucoidan Suppresses Mitochondrial Dysfunction and Cell Death against 1-Methyl-4-Phenylpyridinum-Induced Neuronal Cytotoxicity via Regulation of PGC-1alpha Expression. Mar. Drugs 2019, 17, 518. [CrossRef] [PubMed] 
124. Liang, Z.; Liu, Z.; Sun, X.; Tao, M.; Xiao, X.; Yu, G.; Wang, X. The Effect of Fucoidan on Cellular Oxidative Stress and the CatD-Bax Signaling Axis in MN9D Cells Damaged by 1-Methyl-4-Phenypyridinium. Front. Aging Neurosci. 2018, 10, 429. [CrossRef] [PubMed]

125. Feng, G.; Zhang, Z.; Bao, Q.; Zhang, Z.; Zhou, L.; Jiang, J.; Li, S. Protective effect of chinonin in MPTP-induced C57BL/6 mouse model of Parkinson's disease. Biol. Pharm. Bull. 2014, 37, 1301-1307. [CrossRef] [PubMed]

126. Ebrahimi, S.S.; Oryan, S.; Izadpanah, E.; Hassanzadeh, K. Thymoquinone exerts neuroprotective effect in animal model of Parkinson's disease. Toxicol. Lett. 2017, 276, 108-114. [CrossRef] [PubMed]

127. Ardah, M.T.; Merghani, M.M.; Haque, M.E. Thymoquinone prevents neurodegeneration against MPTP in vivo and modulates alpha-synuclein aggregation in vitro. Neurochem. Int. 2019, 128, 115-126. [CrossRef]

128. Ruankham, W.; Suwanjang, W.; Wongchitrat, P.; Prachayasittikul, V.; Prachayasittikul, S.; Phopin, K. Sesamin and sesamol attenuate $\mathrm{H} 2 \mathrm{O} 2$-induced oxidative stress on human neuronal cells via the SIRT1-SIRT3-FOXO3a signaling pathway. Nutr. Neurosci. 2019, 1-12. [CrossRef]

129. Li, Y.B.; Lin, Z.Q.; Zhang, Z.J.; Wang, M.W.; Zhang, H.; Zhang, Q.W.; Lee, S.M.; Wang, Y.T.; Hoi, P.M. Protective, antioxidative and antiapoptotic effects of 2-methoxy-6-acetyl-7-methyljuglone from Polygonum cuspidatum in PC12 cells. Planta Med. 2011, 77, 354-361. [CrossRef]

130. Ning, B.; Zhang, Q.; Wang, N.; Deng, M.; Fang, Y. beta-Asarone Regulates ER Stress and Autophagy Via Inhibition of the PERK/CHOP/Bcl-2/Beclin-1 Pathway in 6-OHDA-Induced Parkinsonian Rats. Neurochem. Res. 2019, 44, 1159-1166. [CrossRef]

131. Muroyama, A.; Fujita, A.; Lv, C.; Kobayashi, S.; Fukuyama, Y.; Mitsumoto, Y. Magnolol Protects against MPTP/MPP(+)-Induced Toxicity via Inhibition of Oxidative Stress in In Vivo and In Vitro Models of Parkinson's Disease. Parkinsons Dis. 2012, 2012, 985157. [CrossRef]

132. Li, Y.; Wu, Z.; Gao, X.; Zhu, Q.; Jin, Y.; Wu, A.; Huang, A.C. Anchanling reduces pathology in a lactacystininduced Parkinson's disease model. Neural Regen. Res. 2012, 7, 165-170. [CrossRef] [PubMed]

133. Huang, J.Z.; Chen, Y.Z.; Su, M.; Zheng, H.F.; Yang, Y.P.; Chen, J.; Liu, C.F. dl-3-n-Butylphthalide prevents oxidative damage and reduces mitochondrial dysfunction in an MPP(+)-induced cellular model of Parkinson's disease. Neurosci. Lett. 2010, 475, 89-94. [CrossRef] [PubMed]

134. Ahmad, A.S.; Ansari, M.A.; Ahmad, M.; Saleem, S.; Yousuf, S.; Hoda, M.N.; Islam, F. Neuroprotection by crocetin in a hemi-parkinsonian rat model. Pharmacol. Biochem. Behav. 2005, 81, 805-813. [CrossRef] [PubMed]

135. Inoue, E.; Shimizu, Y.; Masui, R.; Hayakawa, T.; Tsubonoya, T.; Hori, S.; Sudoh, K. Effects of saffron and its constituents, crocin-1, crocin-2, and crocetin on alpha-synuclein fibrils. J. Nat. Med. 2018, 72, 274-279. [CrossRef] [PubMed]

136. Rao, S.V.; Hemalatha, P.; Yetish, S.; Muralidhara, M.; Rajini, P.S. Prophylactic neuroprotective propensity of Crocin, a carotenoid against rotenone induced neurotoxicity in mice: Behavioural and biochemical evidence. Metab. Brain Dis. 2019, 34, 1341-1353. [CrossRef]

137. Song, J.X.; Shaw, P.C.; Sze, C.W.; Tong, Y.; Yao, X.S.; Ng, T.B.; Zhang, Y.B. Chrysotoxine, a novel bibenzyl compound, inhibits 6-hydroxydopamine induced apoptosis in SH-SY5Y cells via mitochondria protection and NF-kappaB modulation. Neurochem. Int. 2010, 57, 676-689. [CrossRef]

138. Lee, D.H.; Kim, C.S.; Lee, Y.J. Astaxanthin protects against MPTP/MPP+-induced mitochondrial dysfunction and ROS production in vivo and in vitro. Food Chem. Toxicol. 2011, 49, 271-280. [CrossRef]

139. Chen, L.L.; Song, J.X.; Lu, J.H.; Yuan, Z.W.; Liu, L.F.; Durairajan, S.S.; Li, M. Corynoxine, a natural autophagy enhancer, promotes the clearance of alpha-synuclein via Akt/mTOR pathway. J. Neuroimmune Pharmacol. 2014, 9, 380-387. [CrossRef]

140. Dong, H.; Li, R.; Yu, C.; Xu, T.; Zhang, X.; Dong, M. Paeoniflorin inhibition of 6-hydroxydopamine-induced apoptosis in PC12 cells via suppressing reactive oxygen species-mediated PKCdelta/NF-kappaB pathway. Neuroscience 2015, 285, 70-80. [CrossRef]

141. Sun, X.; Cao, Y.B.; Hu, L.F.; Yang, Y.P.; Li, J.; Wang, F.; Liu, C.F. ASICs mediate the modulatory effect by paeoniflorin on alpha-synuclein autophagic degradation. Brain Res. 2011, 1396, 77-87. [CrossRef]

142. Mao, Y.R.; Jiang, L.; Duan, Y.L.; An, L.J.; Jiang, B. Efficacy of catalpol as protectant against oxidative stress and mitochondrial dysfunction on rotenone-induced toxicity in mice brain. Environ. Toxicol. Pharmacol. 2007, 23, 314-318. [CrossRef] [PubMed] 
143. Tian, L.L.; Zhou, Z.; Zhang, Q.; Sun, Y.N.; Li, C.R.; Cheng, C.H.; Zhong, Z.Y.; Wang, S.Q. Protective effect of (+/-) isoborneol against 6-OHDA-induced apoptosis in SH-SY5Y cells. Cell Physiol. Biochem. 2007, 20, 1019-1032. [CrossRef] [PubMed]

144. Wang, C.Y.; Sun, Z.N.; Wang, M.X.; Zhang, C. SIRT1 mediates salidroside-elicited protective effects against $\mathrm{MPP}(+)$-induced apoptosis and oxidative stress in SH-SY5Y cells: Involvement in suppressing MAPK pathways. Cell Biol. Int. 2018, 42, 84-94. [CrossRef] [PubMed]

145. Li, T.; Feng, Y.; Yang, R.; Wu, L.; Li, R.; Huang, L.; Yang, Q.; Chen, J. Salidroside Promotes the Pathological alpha-Synuclein Clearance Through Ubiquitin-Proteasome System in SH-SY5Y Cells. Front. Pharmacol. 2018, 9, 377. [CrossRef] [PubMed]

146. Sanchis-Gomar, F.; Derbre, F. Mitochondrial fission and fusion in human diseases. N. Engl. J. Med. 2014, 370, 1073-1074. [CrossRef] [PubMed]

147. Calabrese, V.; Santoro, A.; Trovato Salinaro, A.; Modafferi, S.; Scuto, M.; Albouchi, F.; Monti, D.; Giordano, J.; Zappia, M.; Franceschi, C.; et al. Hormetic approaches to the treatment of Parkinson's disease: Perspectives and possibilities. J. Neurosci. Res. 2018, 96, 1641-1662. [CrossRef]

148. Calabrese, E.J.; Mattson, M.P. How does hormesis impact biology, toxicology, and medicine? NPJ Aging Mech. Dis. 2017, 3, 13. [CrossRef]

149. Quiros, P.M.; Mottis, A.; Auwerx, J. Mitonuclear communication in homeostasis and stress. Nat. Rev. Mol. Cell Biol. 2016, 17, 213-226. [CrossRef]

150. Tsang, A.H.; Chung, K.K. Oxidative and nitrosative stress in Parkinson's disease. Biochim. Biophys. Acta 2009, 1792, 643-650. [CrossRef]

151. Gu, Z.; Nakamura, T.; Lipton, S.A. Redox reactions induced by nitrosative stress mediate protein misfolding and mitochondrial dysfunction in neurodegenerative diseases. Mol. Neurobiol. 2010, 41, 55-72. [CrossRef]

152. Klein, C.; Schlossmacher, M.G. Parkinson disease, 10 years after its genetic revolution: Multiple clues to a complex disorder. Neurology 2007, 69, 2093-2104. [CrossRef] [PubMed]

153. Klein, C.; Westenberger, A. Genetics of Parkinson's disease. Cold Spring Harb. Perspect. Med. 2012, 2, a008888. [CrossRef] [PubMed]

154. Dawson, T.M.; Dawson, V.L. The role of parkin in familial and sporadic Parkinson's disease. Mov. Disord. 2010, 25 (Suppl. 1), S32-S39. [CrossRef] [PubMed]

155. Winslow, A.R.; Chen, C.W.; Corrochano, S.; Acevedo-Arozena, A.; Gordon, D.E.; Peden, A.A.; Lichtenberg, M.; Menzies, F.M.; Ravikumar, B.; Imarisio, S.; et al. alpha-Synuclein impairs macroautophagy: Implications for Parkinson's disease. J. Cell Biol. 2010, 190, 1023-1037. [CrossRef]

156. Wang, D.B.; Kinoshita, C.; Kinoshita, Y.; Morrison, R.S. p53 and mitochondrial function in neurons. Biochim. Biophys. Acta 2014, 1842, 1186-1197. [CrossRef]

157. Mogi, M.; Kondo, T.; Mizuno, Y.; Nagatsu, T. p53 protein, interferon-gamma, and NF-kappaB levels are elevated in the parkinsonian brain. Neurosci. Lett. 2007, 414, 94-97. [CrossRef]

158. Wu, X.; Bayle, J.H.; Olson, D.; Levine, A.J. The p53-mdm-2 autoregulatory feedback loop. Genes Dev. 1993, 7, 1126-1132. [CrossRef]

159. Pant, V.; Lozano, G. Limiting the power of p53 through the ubiquitin proteasome pathway. Genes Dev. 2014, 28, 1739-1751. [CrossRef]

160. Haupt, Y.; Maya, R.; Kazaz, A.; Oren, M. Mdm2 promotes the rapid degradation of p53. Nature 1997, 387, 296-299. [CrossRef]

161. Sakaguchi, K.; Herrera, J.E.; Saito, S.; Miki, T.; Bustin, M.; Vassilev, A.; Anderson, C.W.; Appella, E. DNA damage activates p53 through a phosphorylation-acetylation cascade. Genes Dev. 1998, 12, 2831-2841. [CrossRef]

162. Ham, S.; Lee, Y.I.; Jo, M.; Kim, H.; Kang, H.; Jo, A.; Lee, G.H.; Mo, Y.J.; Park, S.C.; Lee, Y.S.; et al. Hydrocortisone-induced parkin prevents dopaminergic cell death via CREB pathway in Parkinson's disease model. Sci. Rep. 2017, 7, 525. [CrossRef]

163. Kang, H.C.; Lee, Y.I.; Shin, J.H.; Andrabi, S.A.; Chi, Z.; Gagne, J.P.; Lee, Y.; Ko, H.S.; Lee, B.D.; Poirier, G.G.; et al. Iduna is a poly(ADP-ribose) (PAR)-dependent E3 ubiquitin ligase that regulates DNA damage. Proc. Natl. Acad. Sci. USA 2011, 108, 14103-14108. [CrossRef] [PubMed]

164. Kim, H.; Park, J.; Leem, H.; Cho, M.; Yoon, J.H.; Maeng, H.J.; Lee, Y. Rhododendrin-Induced RNF146 Expression via Estrogen Receptor beta Activation is Cytoprotective Against 6-OHDA-Induced Oxidative Stress. Int. J. Mol. Sci. 2019, 20, 1772. [CrossRef] [PubMed] 
165. Zeng, X.S.; Geng, W.S.; Jia, J.J. Neurotoxin-Induced Animal Models of Parkinson Disease: Pathogenic Mechanism and Assessment. ASN Neuro 2018, 10, 1759091418777438. [CrossRef] [PubMed]

166. Chen, L.L.; Wang, Y.B.; Song, J.X.; Deng, W.K.; Lu, J.H.; Ma, L.L.; Yang, C.B.; Li, M.; Xue, Y. Phosphoproteomebased kinase activity profiling reveals the critical role of MAP2K2 and PLK1 in neuronal autophagy. Autophagy 2017, 13, 1969-1980. [CrossRef] [PubMed]

167. Bridi, J.C.; Hirth, F. Mechanisms of alpha-Synuclein Induced Synaptopathy in Parkinson's Disease. Front. Neurosci. 2018, 12, 80. [CrossRef]

168. Zbarsky, V.; Datla, K.P.; Parkar, S.; Rai, D.K.; Aruoma, O.I.; Dexter, D.T. Neuroprotective properties of the natural phenolic antioxidants curcumin and naringenin but not quercetin and fisetin in a 6-OHDA model of Parkinson's disease. Free Radic. Res. 2005, 39, 1119-1125. [CrossRef]

169. Ono, K.; Yamada, M. Antioxidant compounds have potent anti-fibrillogenic and fibril-destabilizing effects for alpha-synuclein fibrils in vitro. J. Neurochem. 2006, 97, 105-115. [CrossRef]

170. Pandey, N.; Strider, J.; Nolan, W.C.; Yan, S.X.; Galvin, J.E. Curcumin inhibits aggregation of alpha-synuclein. Acta Neuropathol. 2008, 115, 479-489. [CrossRef]

171. Sharma, N.; Nehru, B. Curcumin affords neuroprotection and inhibits alpha-synuclein aggregation in lipopolysaccharide-induced Parkinson's disease model. Inflammopharmacology 2018, 26, 349-360. [CrossRef]

172. Chen, M.; Wang, T.; Yue, F.; Li, X.; Wang, P.; Li, Y.; Chan, P.; Yu, S. Tea polyphenols alleviate motor impairments, dopaminergic neuronal injury, and cerebral alpha-synuclein aggregation in MPTP-intoxicated parkinsonian monkeys. Neuroscience 2015, 286, 383-392. [CrossRef] [PubMed]

173. Pandareesh, M.D.; Mythri, R.B.; Srinivas Bharath, M.M. Bioavailability of dietary polyphenols: Factors contributing to their clinical application in CNS diseases. Neurochem. Int. 2015, 89, 198-208. [CrossRef] [PubMed]

174. Huang, X.; Li, N.; Pu, Y.; Zhang, T.; Wang, B. Neuroprotective Effects of Ginseng Phytochemicals: Recent Perspectives. Molecules 2019, 24, 2939. [CrossRef] [PubMed]

175. Cho, K.S.; Lim, Y.R.; Lee, K.; Lee, J.; Lee, J.H.; Lee, I.S. Terpenes from Forests and Human Health. Toxicol. Res. 2017, 33, 97-106. [CrossRef] [PubMed]

176. Cicero, A.F.G.; Fogacci, F.; Banach, M. Botanicals and phytochemicals active on cognitive decline: The clinical evidence. Pharmacol. Res. 2018, 130, 204-212. [CrossRef] [PubMed] 